\title{
STUDY ON THE EFFECT OF SOME NANO-MODIFIERS ON THE STRUCTURE AND THE CORROSION RESISTANCE OF OVERLAY WELD METAL
}

\author{
VAnya Dyakova ${ }^{*}$ and Plamen Tashev \\ Institute of Metal Science, Equipment and Technologies, \\ with Hydro- and Aerodynamics Centre "Acad. A. Balevski", \\ Bulgarian Academy of Sciences, \\ 67, Shipchenski Prohod Blvd, 1574 Sofia, Bulgaria, \\ e-mails:v_diakova@ims.bas.bg; ptashev@ims.bas.bg
}

The paper reports a comparative study on the effect of nanomodification with $\mathrm{TiN}, \mathrm{SiC}$, and $\mathrm{TiN}+\mathrm{Cr}$ particles on the microstructure and the corrosion behavior of specimens of overlay weld metal. The specimens are obtained through manual arc overlay welding with coated electrodes E300 both containing nano-size particles in the coating and without nano-modification. The effect of the nano-size particles on the microstructure of the overlay weld metal is identified. The corrosion behavior is studied by means of the method of cyclic immersion in $3.5 \% \mathrm{NaCl}$ for 720 hours. Data on the effect of the type and the concentration of the nanomodifiers on the corrosion resistance of the metal is obtained.

Keywords: nano-modified weld metal corrosion, nano-modifiers TiN, SiC.

\section{INTRODUCTION}

The metallic materials modified with nano-size compositions are characterized by improved mechanical and physical characteristics, which are due to the small grain size and the high relative share of their boundaries according to a number of authors. Considerable progress in the field of manufacture of nanomaterials is achieved by different methods over the last decades. Now the focus of the research is shifted towards the production of useful nano-structures and coatings with higher wear- and corrosion resistance.

Steel is one of the most commonly used construction materials. Different welding technologies are applied for manufacture of the steel constructions.

\footnotetext{
${ }^{*}$ Corresponding author.
}

DOI: 10.7546/EngSci.LV.18.04.03

(C) Инженерни науки, год. LV, 2018, № 4 
The engineer constructions however corrode easily due to the high sensitive to environmental impact during service. The corrosion of the welded constructions in acidic aqueous solutions is one of the main problems in many industries. Corrosion inhibitors are added in order to prevent degradation of the base metal and the weld metal. The most well-known acidic inhibitors are compounds containing nitrogen, sulfur, and oxygen atoms. The inhibitory effect is due to their adsorption on the metal surface. Besides the high inhibitory efficacy, the good quality of the inhibitor is determined by the low cost, the low toxicity and the easy manufacture.

Over the last two decades the nano-technology plays an important role in the corrosion protection of metals [1,2]. Although scarce data on the effect of some nano-modifiers (NMs) are found in the scientific literature, which were initially intended to improve the mechanical properties of the metal but actually act as corrosion rate inhibitors $[3,4,5,6]$.

The nano-modifiers show advantages similar to those of the organic inhibitors but without their adverse effect on the environment and they are an effective alternative to the dangerous and toxic compounds.

There is data for increased hardness and wear resistance of the overlay weld metal obtained by manual arc welding using electrodes with nano-size particles introduced in their coating [7-9]. Usually in order to improve the wear resistance of the surfaces after welding and machining, the parts are subjected to an adequate heat treatment. Data on how the nano-modifiers introduced to improve the hardness and wear resistance of welding electrodes influence the rate of corrosion of the weld is still insufficient.

This study is aimed to investigate how the nano-modifiers $\mathrm{TiN}, \mathrm{SiC}$, and $\mathrm{SiC}+\mathrm{Cr}$ introduced in the coating of a basic IZA E300 welding electrode with purpose to increase the hardness and wear resistance of the overlay weld metal influence its microstructure and corrosion resistance.

\section{EXPERIMENTAL}

\subsection{Tested materials}

The test series of nano-modified electrodes are developed on the base of electrode IZA E300 for overlay welding of already worn surfaces or for preventive welding. The electrode wire has diameter $\varnothing 3.25 \mathrm{~mm}$ and length $450 \mathrm{~mm}$. The technological properties of the manufactured test electrodes are determined [8]. The surface overall weld was carried out on the low-alloy low-carbon steel S235JR in three layers.

(C) Инженерни науки, год. LV, 2018, № 4 
TABLE 1. Chemical composition of the overlay metal

\begin{tabular}{|c|c|c|c|}
\hline $\mathrm{C}[\%]$ & $\mathrm{Mn}[\%]$ & $\mathrm{Si}[\%]$ & $\mathrm{Cr}[\%]$ \\
\hline $0.1-1.5$ & $1.6-1.8$ & $0.4-0.8$ & $0.8-1.2$ \\
\hline
\end{tabular}

The type of the electrode coating is basic. The chemical composition of the overlay metal is given in Table 1 .

The nano-modification is carried out according to the specific technology with addition of different quantities of nano-size powders of TiN, SiC, and TiN+Cr. For better wetting and absorption and hence higher efficiency, the nano-powders are activated mechanically beforehand in a ball mill. Potassium water glass is used as binding agent of the coating.

The quantity of the added nano-materials is at the cost of the iron content. The coating materials have been delivered and graded individually in accordance with the technical requirements. According to the manufacturer's data, the size of TiN particles is $(50 \pm 5) \mathrm{nm}$, and the size of $\mathrm{SiC}$ particles is $(60 \pm$ 5) $\mathrm{nm}$.

Cylindrical test specimens with diameter $\varnothing 8 \mathrm{~mm}$ and height $20 \mathrm{~mm}$ for hardness, micro hardness and wear resistance testing were obtained from the overlay welded and machined plate by water cutting [9-13]. Ultrasonic comparative assessment of the internal incompleteness of the nano-modified layers was performed [14].

The test specimens for metallography and corrosion resistance are cut off of the top layer of a plate of low-alloy low-carbon steel S235JR with three surface layers welded with electrode IZA E300. The hardness of the surface layers allows for subsequent machining. The nano-modifier added in the coating of electrode IZA E300 is aimed to increase the wear resistance of the overlay layer attaining the needed operational properties without subsequent heat treatment and thus to improve the efficiency of the process.

\subsection{Test specimens}

The test specimens for corrosion resistance of the overlay metal are selected among the specimens that showed some change of the hardness and wear resistance after nano-modification in a preliminary study. The reference specimen is taken from material obtained using the basic electrode IZA E300 without nano-modification. Three discs about $1 \mathrm{~mm}$ thick each are cut from the top of the welded metal of each specimen. For each case one disc of the set was subjected to metallographic analysis and two were subjected to corrosion tests.

(c) Инженерни науки, год. LV, 2018, № $4 \quad 39 \quad$ (c) Engineering Sciences, LV, 2018, No. 4 
TABLE 2. Content of the nano-modifier in the electrode coating composition

\begin{tabular}{|c|c|}
\hline & Amount of nano-modifier in coating [\%] \\
\hline Specimen No & no nano-modifier \\
\hline E300 & $0.1 \% \mathrm{TiN}$ \\
\hline 1.1 & $0.4 \% \mathrm{TiN}$ \\
\hline 1.2 & $3.0 \% \mathrm{TiN}$ \\
\hline 1.3 & $0.4 \% \mathrm{SiC}$ \\
\hline 2.1 & $1.5 \% \mathrm{SiC}$ \\
\hline 2.2 & $1.5 \% \mathrm{TiN}+\mathrm{Cr}$ \\
\hline 3.1 & \\
\hline
\end{tabular}

The designations of the tested specimens, the type and content of the nanomodifier in the coating are given in Table 2.

\subsection{Test methods}

The microstructure of the overlay weld metal was analyzed by the light microscopy (LM) method. For this purpose, metallographic specimens were polished and etched with $4 \% \mathrm{HNO}_{3}$ to develop the microstructure. The observation was carried out using JELAVERT metallographic microscope by Carl Zeiss.

The corrosion resistance of the overlay weld metal is investigated by periodic immersion in $3.5 \%$ aqueous solution of $\mathrm{NaCl}$ followed by drying. The overall duration of the testing is 720 hours, as the ratio of the total immersion time to the total drying time being 1:1. After the test is completed, the corrosion products are removed and the mass loss indicator $\Delta \mathrm{m}\left[\mathrm{g} / \mathrm{m}^{2}\right]$ is identified, and the corrosion rate $K\left[\mathrm{~g} / \mathrm{m}^{2} \mathrm{~h}\right]$ is calculated.

\section{RESULTS ANS DISCUSSION}

\subsection{Microstructure test}

The metallographic investigation showed that all specimens had Widmanstatten type ferrite-perlite microstructure. The ferrite is acicular, as the size of the needles varies widely.

Figures 1 and 2 display the images of microstructures obtained with electrodes with different concentrations of NM in the coating.

Table 3 shows the change in the type of microstructure of the tested specimens depending on the type and content of nano-modifiers.

(c) Инженерни науки, год. LV, 2018, № $4 \quad 40$ (C) Engineering Sciences, LV, 2018, No. 4 


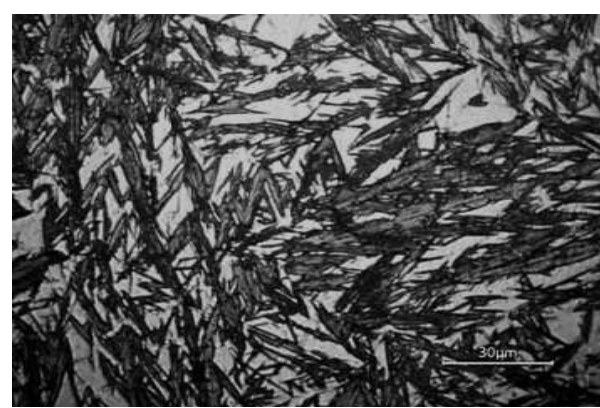

(a)

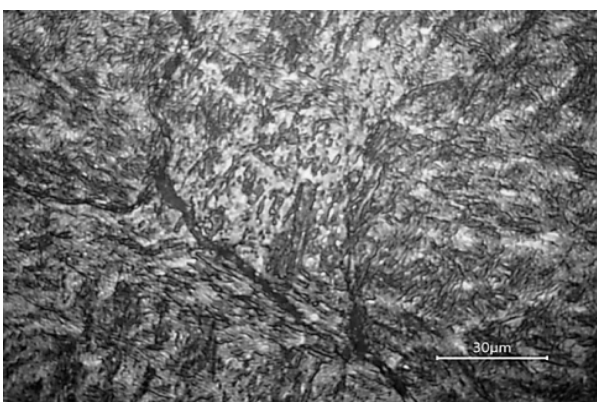

(c)

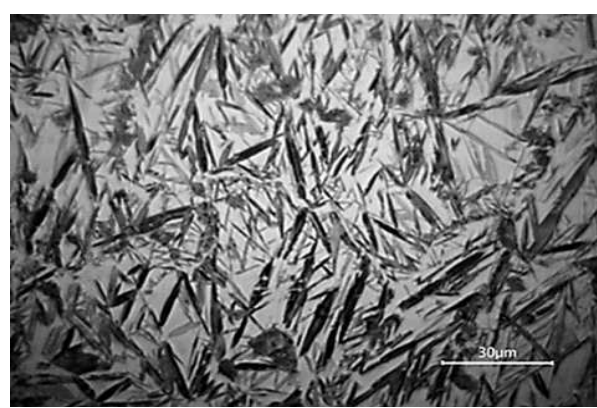

(b)

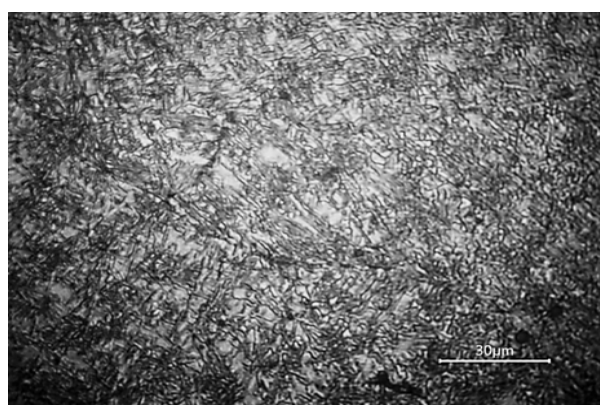

(d)

Fig. 1. Microstructure of the overlay weld metal: (a) specimen $2.1(0.4 \% \mathrm{SiC})$; (b) specimen $1.2(0.4 \% \mathrm{TiN})$; (c) specimen E300; (d) specimen $3.1(1.5 \%(\mathrm{TiN}+\mathrm{Cr})$

TABLE 3. Change of the microstructure of overlay weld metal

\begin{tabular}{|c|c|c|c|c|c|c|c|}
\hline & $\begin{array}{l}\text { Most } \\
\text { coarse- } \\
\text { grain } \\
\text { structure }\end{array}$ & & & & & & $\begin{array}{l}\text { Most } \\
\text { fine-grain } \\
\text { structure }\end{array}$ \\
\hline Specimen No & 2.1 & 1.2 & & 3.1 & 1.3 & 2.2 & 1.1 \\
\hline$[\%]$ & $0.4 \%$ & $0.4 \%$ & E300 & $1.5 \%$ & $3.0 \%$ & $1.5 \%$ & $0.1 \%$ \\
\hline $\mathrm{HM}$ & $\mathrm{SiC}$ & TiN & & $(\mathrm{TiN}+\mathrm{Cr})$ & $\mathrm{TiN}$ & $\mathrm{SiC}$ & TiN \\
\hline Specimen No & & 1.2 & & & 1.3 & & 1.1 \\
\hline$[\%]$ & & $0.4 \%$ & E300 & & $3.0 \%$ & & $0.1 \%$ \\
\hline TiN & & $\mathrm{TiN}$ & & & $\mathrm{TiN}$ & & $\mathrm{TiN}$ \\
\hline Specimen No & 2.1 & & & & & 2.2 & \\
\hline$[\%]$ & $0.4 \%$ & & E300 & & & $1.5 \%$ & \\
\hline $\mathrm{SiC}$ & $\mathrm{SiC}$ & & & & & $\mathrm{SiC}$ & \\
\hline $\begin{array}{c}\text { Specimen No } \\
{[\%]} \\
(\mathrm{TiN}+\mathrm{Cr})\end{array}$ & & & E300 & $\begin{array}{c}3.1 \\
1.5 \% \\
(\mathrm{TiN}+\mathrm{Cr})\end{array}$ & & & \\
\hline
\end{tabular}

(c) Инженерни науки, год. LV, 2018, № 4

41

(c) Engineering Sciences, LV, 2018, No. 4 


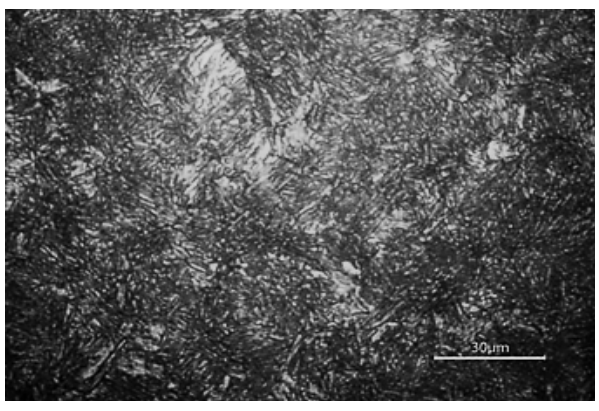

(a)

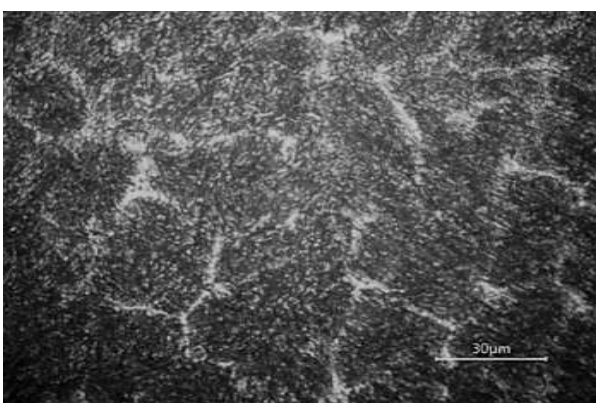

(b)

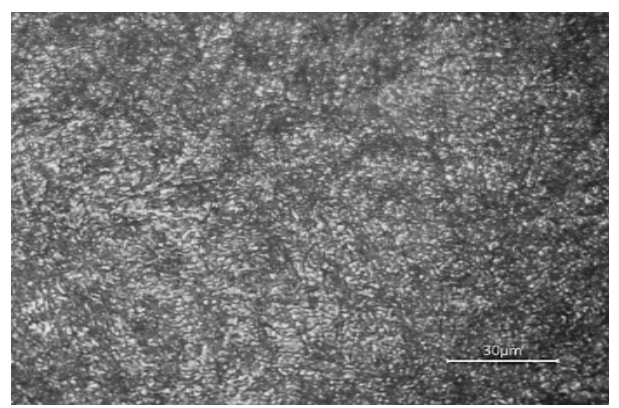

(c)

Fig. 2. Microstructure of the overlay weld metal: (a) specimen $1.3(3 \% \mathrm{TiN})$; (b) specimen $2.2(1.5 \% \mathrm{SiC})$; (c) specimen $1.1(0.1 \% \mathrm{TiN})$

The most coarse-grain structures are observed in specimen 2.1 and specimen 1.2 obtained after overlay welding with electrodes containing respectively $0.4 \% \mathrm{TiN}$ and $0.4 \% \mathrm{SiC}$ in the coating. In these cases the length of the needles is in the range 25 to $30 \mu \mathrm{m}$, and the width is 4 to $5 \mu \mathrm{m}$. No microstructure orientation is observed. At the same concentrations $0.4 \%$ of the nano-modifiers, the microstructure of the specimens modified with $\mathrm{SiC}$ is slightly coarser than that of the specimens modified with TiN. These structures have grain size about 20 times larger than the structures obtained with the reference electrode E300, in which orientation of the ferrite needles in different crystallographic directions is observed.

It was found that the grain size of the specimens obtained with electrodes modified with TiN with concentrations $3 \%$ and $0.1 \%$ is smaller than that of the specimens obtained with the reference electrode E300. There is a pronounced orientation of the ferrite needle in the microstructure of specimens 3.1, 1.3, and 2.2 but such orientation is absent in the fine structure of specimen 1.1.

(c) Инженерни науки, год. LV, 2018, № 442 (c) Engineering Sciences, LV, 2018, No. 4 


\subsection{Results from the corrosion test}

The results obtained from the corrosion tests are given in Table 4. All data are the average values of the results of two specimens tested in parallel.

TABLE 4. Corrosion rate

\begin{tabular}{|c|c|c|c|c|c|c|c|}
\hline & $\begin{array}{c}\text { Highest } \\
\text { corrosion } \\
\text { rate } K\end{array}$ & & & & & & $\begin{array}{l}\text { Lowest } \\
\text { corrosion } \\
\text { rate } K\end{array}$ \\
\hline Specimen & 1.1 & E300 & 1.2 & 1.3 & 2.2 & 2.1 & 3.1 \\
\hline $\begin{array}{c}\%] \\
\mathrm{HM}\end{array}$ & $\begin{array}{l}0.1 \% \\
\text { TiN }\end{array}$ & - & $\begin{array}{l}0.4 \% \\
\text { TiN }\end{array}$ & $\begin{array}{l}3.0 \% \\
\text { TiN }\end{array}$ & $\begin{array}{c}1.5 \% \\
\mathrm{SiC}\end{array}$ & $\begin{array}{c}0.4 \% \\
\mathrm{SiC}\end{array}$ & $\begin{array}{c}1.5 \% \\
(\mathrm{TiN}+\mathrm{Cr})\end{array}$ \\
\hline $\begin{array}{c}K \\
{\left[\mathrm{~g} / \mathrm{m}^{2} \mathrm{~h}\right]}\end{array}$ & 1.69537 & 1.67880 & 1.63424 & 1.55262 & 1.33520 & 1.29664 & 1.21834 \\
\hline Group & \multicolumn{3}{|c|}{ IV } & III & \multicolumn{2}{|c|}{ II } & $\overline{\mathrm{I}}$ \\
\hline
\end{tabular}

The test specimens may be divided in four groups depending on the value of the corrosion rate $K$ of the overlay metal:

Group I: specimen $3.1(1.5 \% \mathrm{TiN}+\mathrm{Cr})$;

Group II: specimens $2.1(0.4 \% \mathrm{SiC})$ and $2.2(1.5 \% \mathrm{SiC})$;

Group III: specimen $1.3(3.0 \% \mathrm{TiN})$;

Group IV: specimens E300, 1.2 (0.4\% TiN), 1.1 (0.1\% TiN).

The division in groups is based on the following assumption: if the difference in the values of $K$ for two neighbor specimens is less than $5 \%$, the specimens are classified in the same group; if the difference of $K$ exceeds $5 \%$, the specimens belong to different groups.

Group I contains only specimen 3.1 with the lowest corrosion rate. This result is explained with the presence of $\mathrm{Cr}$ in the composition of the nanomodifier. There are evidences available for the beneficial effect of $\mathrm{Cr}$ as corrosion inhibitor of nano-structure specimens [5]. The differences in the $K$ values for the groups II and IV specimens may be considered to be within the uncertainty limits of the test resulting from the measurement of the specimens sizes and the weight of the masses before and after removal of the corrosion products.

It is seen from the data obtained that the modification of the welding electrodes with TiN up to $0.4 \%$ does not significantly influence the corrosion resistance of the overlay metal. There is a slight increase of the corrosion resistance at concentration $3.0 \% \mathrm{TiN}$, and the best corrosion resistance is obtained at concentration $1.5 \%(\mathrm{TiN}+\mathrm{Cr})$.

The values of $K$ of the overlay metal obtained with electrodes with $0.4 \%$ $\mathrm{SiC}$ or $1.5 \% \mathrm{SiC}$ are similar but significantly lower than the values of $K$ for

(c) Инженерни науки, год. LV, 2018, № 443 (c) Engineering Sciences, LV, 2018, No. 4 
the same concentrations of the modifier TiN, meaning that the nano-modifier $\mathrm{SiC}$ acts better as corrosion inhibitor than TiN.

\section{CONCLUSION}

- The metallographic study showed that the microstructure of the overlay weld metal obtained with electrodes nano-modified with $0.4 \%$ TiN or $0.4 \%$ $\mathrm{SiC}$ is larger than weld metal microstructure obtained with the reference electrode E300.

- It is not possible to identify the exact dependence between the size of the grains and the concentration of the modifier through metallographic analysis, hence additional Electron BackScatter Diffraction (EBSD) analysis is needed. The EBSD analysis allows performing a quantitative analysis in terms of the grain size depending on grains number in the area of a particular crystallographic plane.

- The corrosion resistance of the overlay metal depends on the type and the concentration of the nano-modifier. The highest corrosion resistance is achieved after introduction of nano-particles of ( $\mathrm{TiN}+\mathrm{Cr}$ ).

- The modification with $\mathrm{SiC}$ showed better results for corrosion resistance compared to TiN.

- There is no correlation identified between the corrosion resistance of the overlay weld metal and the grain size of its microstructure.

- To obtain more accurate dependences of the corrosion rate on the type and the amount of nano-modifiers, it is envisaged to extend the scope of the investigation by increasing the factor concentration levels of the modifier. To reduce the relative share of the test uncertainty in the final result for corrosion rate, it is planned to increase the number and the size of the tested specimens in each series.

\section{REFERENCES}

[1] R. S. Abdel Hameed, Abd-Alhakeem H. Abu-Nawwasb and H. A. SheHATAA, Nano-composite as corrosion inhibitors for steel alloys in different corrosive media, Pelagia Research Library, Advances in Applied Science Research (2013) 4 (3) 126-129.

[2] H. A. JEHN, Improvement of corrosion resistance of PVD hard coating substrates, Surface and Coatings Technology (2000) 125 212-217.

[3] A. J. Novinrooz, H. Seyedi and M. M. Larigani, Microhardness study of $\mathrm{Ti}(\mathrm{C}, \mathrm{N})$ films by Hallow Cathode Discharge Gun, Journal of Achievements in Materials and Manufacturing Engineering (2006) 14 59-63.

(c) Инженерни науки, год. LV, 2018, № 4

44

(c) Engineering Sciences, LV, 2018, No. 4 
[4] M. I. Jones AND I. R. MCColl, Effect of substrate preparation condition of TiN coating by RF sputtering, Surface and Coatings Technology (2000) 132 143151.

[5] A. J. Novingooz, N. Afshari And H. Seyedi, Improvement of hardness and corrosion resistance of SS- 420 by $\mathrm{Cr}+\mathrm{TiN}$ coatings, Journal of Achievement in Materials and Manufacturing Engineering (2007) 23 (1).

[6] V. Dyakova and Yo. Kostova, Comparative Study on the Corrosion Resistance of Specimens from Non-Modified and Nano-Modified Steel GX120Mn12, Engineering Sciences (2018) LV (1) 61-71, DOI:10.7546/EngSci.LV.18.01.05.

[7] P. Tashev, H. Kondov, Y. Lukarski and E. Tasheva, Development of nanomodified electrodes for manual arc welding, hardness of the overlay layer, Engineering Sciences (2015) LII (3) 71, ISSN 1312-5702 (in Bulgarian).

[8] P. Tashev, H. Kondov and A. Tasev, Technological properties of nanomodified electrodes for manual arc welding, Proceedings of Fourth National Conference with International Participation "Metal Science, Hydro- and Aerodynamics, National Security'2014", 23-24 October 2014, Sofia, pp. 75-79, ISSN 1313-8308 (in Bulgarian).

[9] P. Tashev, H. Kondov, E. Tasheva and M. Kandeva, Study on hardness and wear resistance of layers overlayed using electrodes with nano-modified coating, International Journal of Engineering and Applied Sciences, Islamabad, Pakistan (2015) 06 (04) 01-06, ISSN 2305-8269.

[10] P. Tachev, H. Kondov, M. Kandeva and E. Tasheva, Wear-resistance study of nano-modified coatings by TIG surfacing process, SERBIATRIB'15, $14^{\text {th }}$ International Conference on Tribology, Belgrade, Serbia, 13-15 May 2015, ISBN 978-86-7083-857-442.

[11] P. Tashev, H. Kondov, E. Tasheva and A. Tasev, Durability of nanomodified layers produced by manual arc overlay welding, The $3^{\text {rd }}$ IIW South-East European Welding Congress "Welding and Joining Technologies for a Sustainable Development and Environment", June 3-5, 2015, Timişoara, Romania, pp. 267271, ISBN 978-606-554-955-5.

[12] P. Tashev, H. Kondov, R. Lazarova and R. Dimitrova, Research on Nanomodified Layers obtained in Manual Arc Welding, Collection of Reports, $28^{\text {th }}$ International Scientific Conference of the Faculty of Industrial Technology of the Technical University of Sofia "70 Years of MTF", 11-13 September 2015, Sozopol, pp. 197-205, ISSN 978-619-167-178-6 (in Bulgarian).

[13] P. Tashev, H. Kondov, S. Valkanov and E. Tasheva, Scanning electron microscope examination of layers weld overlaid with nano-modified electrodes, Academic journal "Mechanics Transport Communications" (2016) 15 (3/1) article No 1331, ISSN 1312-3823 (print), ISSN 2367-6620 (online).

[14] I. Kolarov and P. TAshev, Ultrasonic comparative assessment of internal incompleteness in welded nanomodified layers, Acoustics (2014) XVI (16), ISSN 1312-4897, National Scientific and Technical Conference "Acoustics'2014", 28 29.11.2014, TU Sofia, pp. 48-53 (in Bulgarian).

(c) Инженерни науки, год. LV, 2018, № 4

45

(c) Engineering Sciences, LV, 2018, No. 4 


\title{
ИЗСЛЕДВАНЕ НА ВЛИЯНИЕТО \\ НА НАНОМОДИФИКАТОРИ ВЪРХУ \\ СТРУКТУРАТА И КОРОЗИОННАТА УСТОЙЧИВОСТ НА НАВАРЕН МЕТАЛ
}

\author{
ВАНЯ ДяковА* ${ }^{*}$ И ПЛАМЕН ТАШЕВ
}

Институт по металознание, сгорбжения и технологии с Центгр по хидро- и аеродинамика „Акад. Ангел Балевски“, Българска академия на науките, бул. Шипченски проход № 67, 1574 София, Бблгария, e-mails:v_diakova@ims.bas.bg; ptashev@ims.bas.bg

Резюме. Изследвано е влиянието на наноразмерни частици от $\mathrm{TiN}, \mathrm{SiC}, \mathrm{TiN}+\mathrm{Cr}$ върху микроструктурата и корозионното поведение на образци от наварен метал. Образците са получени чрез ръчно електродъгово наваряване с обмазани електроди E300 с наноразмерни частици в обмазката и такива без наномодифициране. Установено е влиянието на наноразмерните частици върху микроструктурата на наварения метал. Корозионното поведение е изследвано чрез метода на циклично потапяне в $3,5 \% \mathrm{NaCl}$ в продължение на 720 часа. Получени са данни за влиянието на вида и концентрацията на наномодификаторите върху корозионната устойчивост на метала.

Ключови думи: корозия на наномодифициран и наварен метал, наномодификатори $\mathrm{TiN}, \mathrm{SiC}$.

Received October 01, 2018 